\title{
Developing European Citizien Model Through Language Learning Process
}

\author{
Prof. Assoc. Dr. Migena Alimehmeti \\ University of Tirana, Albania, Faculty of Foreign Languages \\ migena22001@yahoo.com,
}

\author{
DOI:10.5901/mjss.2014.v5n19p147
}

\begin{abstract}
The learning of a foreign language goes beyond the acquisition of knowledge. What is at issue in the learning process is in terms of values such as learning tolerance and peace. It is to educate and prepare students to open themselves to another culture, to confront a different way of life and thinking. While learning a foreign language, the student comes into contact with another lifestyle, habits and tradition. He will find out that in Europe nothing is ever totally different or quite similar. The learning of a foreign language does not imply linguistic and communicative skills only, but also the education of the future European citizen. For purposes of this study, we have carried out a questionnaire with about 126 pupils and students. The purpose of this questionnaire is to highlight their capacity to develop a European citizen model through language learning process. Considering their responses, it is noted that our pupils and students focus mainly on learning a foreign language as a separate process without linking it directly with the recognition of another civilization. Also, pupils have not many information about the two concepts: the European citizen and national citizen. They consider this concepts as separate from one-another. Other questions in this questionnaire are focused on issues such as for example the organization of debates as language activity; if they feel active during the debates; if they have ever felt prejudiced during this activity in class; how are resolved a "conflict" situation created in class; if they are able to distinguish the intolerance symptoms like the prejudice, stereotype, ostracism.
\end{abstract}

Key words: European citizen, foreign language teaching, discussions, intolerance.

\section{Introduction}

The objective of this paper is to point out that the learning of a foreign language implies not only linguistic and communicative skills but also the education of the future European citizen. Various publications by European organizations (OECD, UNESCO) and the Treaty of Maastricht have been analyzed. The main conclusions show that the foreign language curriculum creates more opportunities and practical patterns for students to become genuine citizens of Europe, which Albania aims to become a member of in the future.

The relationship between languages, culture and politics also has called the attention of all educators, but particularly foreign language and culture educators, who must define and redefine their practices within this new educational landscape. [....] and foreign language curriculum needs to take on a more critical dimensions in both its content and instruction practices [...] how the language and the culture curriculum is perhaps the most suitable area of the curriculum to develop citizens who are critically and socially responsible inhabitant of the planet (Gilherme, M. 2002).

Today's societies are becoming increasingly multilingual and multicultural. The school has an essential role to play in ensuring the peaceful nature of interpersonal relationships. Communication is one of the key objectives and priority means in teaching a foreign language and language is closely related to cultural dimensions of the communities.

The concept of European citizenship has emerged for the first time in the Maastricht Treaty in 1992 (Treaty of Maastricht, 1992).

"One of the major innovations established by the Treaty is the creation of European citizenship over and above national citizenship. Every citizen who is a national of a Member State is also a citizen of the Union."

European citizenship does not replace national citizenship; on the contrary, it complements it by granting new rights to any persons who are nationals of a Member State of the Union. In Europe, citizenship is based on the respect for justice, for human rights. (Part two, article 8.1, 8.2, 8a, 8b, 8c. 8c, 8d.)

Learning a foreign language means discovering the Other, speaks his/her language, accepts without reticence another system of signs, another way of thinking, living. 
The citizen of the future is likely to remain the spectator of the mechanisms in which he has no part. The European countries are seen by the pupils and students as future lands to live, work and study. Does the school have the means and opportunity to prepare its pupils and students to this physical and mental mobility?

To realize this approach it should be noted that being a European citizen implies a specific educational approach. Citizenship is inclusive because it is based on the "common rights".

The person, who aspires to become a citizen of EU, must be able to evaluate the situations, make decisions and discuss. He should possess critical thinking, have communication skills and get engaged in action.

This study focuses on the role of the school in the education of citizenship.

A fundamental objective of language teaching is to develop the communication skills of learners. The language classroom becomes the environment in which the ability to listen to others is exercised and developed, where learners become aware that the sharing of perspectives can be rewarding. This dimension is emphasized in the action-oriented approach in which the learner is considered a social actor who performs tasks in a given context and in a particular area (Puren, C. 1988).

We cannot separate learning a language from the culture it conveys. The cultural aspect is very important for the acquisition of the communicative competence in foreign languages (CECR, 2001). Recommendation 1383 (1998) of the Parliamentary Assembly on Linguistic Diversification calls for the promotion of a type of education that puts more emphasis on the culture and society of the countries concerned (Report of the committee in Cultural and Education, 1998).

Beyond the cultural and practical dimensions, a command of foreign languages is a decisive factor in understanding between peoples, tolerance of other communities, be they indigenous or foreign, and peace between nations, as well as being an effective barrier against the return of barbarity in its various guises.

to promote a type of education that places greater emphasis on the culture and society of the countries concerned;

To promote mutual understanding and tolerance, respect for identities and cultural diversity through more effective international communication.

[...]. The second summit made democratic citizenship as a priority educational objective, thus giving added importance to a further objective pursued in recent projects, namely:

To promote methods of modern language teaching which will strengthen independence of thought, judgment and action, combined with social skills and responsibility (CERF, 2002).

\section{Method}

Foreign language teaching and learning process have a role to play as part of an interdisciplinary approach to a positive culture. Knowing another culture allows learners to accept the fact of the existence of multiple identities. The intercultural dimension of language learning has the potential to promote anti-racism. Learning means also less ignorance that is the basis of intolerance and racism (Legendre, J. 1998).

Teaching and learning languages processes, associated with pedagogical experiences, can greatly contribute to a culture of human rights. This perspective is underlined by the Common European Framework of reference for languages (CERF, 2002): to experience a tolerant approach to language class prepares learners to go beyond the school context. Language teaching process is a great way to promote the values that encourage the development of a culture of peace, mutual respect and tolerance.

\section{Participants}

A questionnaire was designed to better understand the situation of our learner and student in Albania with regard to the possibility and indispensability of developing a European citizen model during the foreign language learning process.. This questionnaire was answered by high and higher schools' learners and students. Four groups of class of about 126 students in total participated in this questionnaire. Learners and students respondents to the questionnaire came from the following schools: Petro Nini Luarasi , Partizani, Faculty of Foreign Language and Faculty of Law in Tirana.

The questionnaire questions were closed-ended questions so as to make it easier to collect and process the data outcome. This method enables collecting answers about many topics in a short period of time and it provides access to a great number of learners and students. 


\section{Materials}

The data collected through the questionnaire have a quantitative nature. The questionnaire aims to know if the students are actively involved in debates, take part in decision-making, or if they see that the school encourages them in term of citizenship.

The data has been collected and shown in separate graphics which have made it possible to interpret the yielded results as well.

The questionnaire focuses on issues such as, learning a foreign language helps them to find out another way of thinking, of civilization, how they find the two concepts of European citizen and the national citizen, if the foreign language classes give explicitly issues /topics related to the model of European citizen, if they organize brainstorming sessions during classes.

The students had to choose between three or four possible replies, which are analyzed and provided in the graphic.

\section{Procedures}

The questionnaires were completed by the learners and students in classrooms. The authors of this study were present, too. The learners and students were given all the time needed. This particular method was seen as a very effective way for the collective administration of the questionnaires so that to avoid the outside influence on individual answers and to remove any doubts the respondents might have concerning certain questions. The questionnaire was conducted in May 2014. It was completed by 126 learners and students.

Classification tables in which different categories of possible answers were grouped was the first step of entering the data.. And since the questionnaire was neither digital nor electronic the data was entered manually. All the analyzed data was first entered into the tables printed on paper and then into the computer in order to minimize human errors in this process. Both data transfer processes were double-checked to then continue with the percentage calculation of the given answers. The descriptive method and the frequency analysis was the used for the two tables.

\section{Results}

With regard to the first question (Fig. 1), pupils and students' responses show that most of them ( $48 \%$ of the pupils, $61 \%$ of the students) consider learning a foreign language as a process of knowing a language. This response is followed by the option that this process is also linked to the recognition of a culture of another country, $(25 \%$ of the pupils and $41 \%$ of the students). A small part of them (19\% of the pupils and $13 \%$ of the students) agree that learning a foreign language implies a different way of thinking.

Considering these responses, we conclude that our pupils and students focus mainly on learning a foreign language as a separate process, without directly linking it with the recognition of another civilization and therefore, also of another way of thinking. We have to make pupils and students aware that learning a foreign language is simply acquiring knowledge of new words and grammar rules but it is a far broader process.

With regard to the second question (Fig. 2), the pupils' responses differ from those of the students. $81 \%$ of the pupils see the two concepts (European citizen and national citizen) as separate from one-another; whereas the students think it differently. $66 \%$ of them see them as complementary to one-another. We propose that the awareness rising as regards these two concepts should start earlier, during the pre-university education.

In their answers of the third question (Fig.3), if the learning of a foreign language prepares them mentally and physically to achieve satisfactorily the model European citizen, the majority of pupils (73\%) and students (78\%) responded positively. This fact should be used and integrated visibly in the teaching process of a foreign language; it will also influence to a higher motivation of pupils and students.

In answering the fourth question (Fig. 4), the majority of pupils (39\%) and students (72\%), argue that the debate activities are organized during the foreign language process. But the percentage of students is higher than that of pupils. In addition, almost half of the pupils claim that they perform this activity from time to time. Considering the responses from the students, we have to accept that perhaps such brainstorming activities should be a common and frequent phenomenon in the classrooms. Thus the students will be introduced presented earlier with the "laws" of running a brainstorming session, and be patient to listen and to respect the opinion of interlocutors, giving justified arguments, etc. 
As regards the fifth question (Fig.5), the responses are result of the ongoing or fourth question. We note again that the participation of language students (58\%) in debates is higher than that of pupils $(22 \%)$

One of the worries of an individual during a debate is the fear of prejudice. Considering the answers to question six (Fig.6), we conclude that this phenomenon occurs, from time to time, in the majority of pupils (42\%) and students (40\%). Moreover, $32 \%$ of the pupils feel it constantly. Our task, as teachers, is to find ways, techniques and strategies to avoid this phenomenon.

Regarding the seventh question (Fig.7), we conclude that the responses of pupils do not match with those of students. $50 \%$ of the students claim that they are able to resolve themselves the situation of a "conflict" during the debate. While, $44 \%$ of the pupils admit the teacher's intervention in that case.

The role of teachers is necessary as he should be trained to continuously and actively participate in continuous professional development. He/ she should be the first to distinguish the symptoms of intolerance in the community.

By considering the eighth question (Fig. 8), we conclude that the pupils (75\%) feel it as ridiculous, while students, in the majority $(37 \%)$, as prejudiced. Pupils do not have clear meanings of the terms "prejudice" and "stereotype". They label every phenomenon of intolerance with the term "ridiculous".

In their responses to the ninth question (Fig.9), the majority of the pupils (46\%) claim they were not presented directly with issues related to the knowledge about the European model citizen. Whereas, a part of students (36\%) admit they have had this opportunity in learning a foreign language process and only $32 \%$ of them state that this opportunity was given occasionally.

Our duty as e teacher and also teaching methods maker is deal directly with issues related the European citizen pattern.

Discussion

The foreign language class is a unit for learning democratic citizenship. This process is realized through these factors: knowledge (the curricula), skills (communication skills).

Language teaching requires and maintains a meaningful part of the school programs. The programs put emphasis on the flexibility of language teaching content, which covers the study of literature, culture, media, debates and actuality matters.

Foreign language teachers are not always aware of the contribution that they can make to citizenship education (civic education).

According to English Dictionary for Advancer Learners (2001), the teacher is a person who teaches, usually as a job at school or similar institution and to teach means giving to somebody instructions so they know about it or how to do it. To teach also means to make someone think, feel or act in a different way, and to teach about a subject, the teacher helps students to learn about it by explaining it or showing them how to do it as a job at a school, college or university.

Le petit Robert (2004) defines the teacher as someone who teaches, or is in charge of teaching, as well as the teaching staff of teachers and educators. As far as the process of teaching is concerned, this dictionary defines it as learning the way to react/behave and think; an action or art of teaching, conveying knowledge to the learner.

According to the TALIS survey (TALIS survey provides information on the form, content and contextual conditions of teacher professional development in 24 countries. OECD, 2010), "the professional development is defined as activities that develop an individual's skills, knowledge, expertise and other characteristics as a teacher".

Teachers must be careful regarding the continuity of their professional development.

There are teachers who, inspired by participation in European projects and meetings, were the first in the citizenship education languages teaching.

The role assigned to teachers who are given the status of "transformative intellectuals" within the project for democratic citizenship educations fits into an emancipator view of citizenship education that enables them and students to become empowered citizens and whose contribution to democracy is not simply the electoral vote or obeying the laws but also active and critical participation in community life (Gilherme, M.2002).

Pedagogical content associated with language learning is a second dimension in the contribution of languages to citizenship since the development of communicative methods is democratic. Competencies cultivated in language classes are directly transferable to education for citizenship. During an advanced communication such as formal debate, the learner must 
mobilize all its knowledge about the culture, vocabulary and grammar, the arguments, agreements and disagreements, response, listening, use of a persuasive tone, the ability to contain and be polite, etc.

According to Tardieu (1999.24), we find that the language classroom is a place where education through dialogue occupies a privileged place. During the class of foreign language, the learners are often asked to speak and discuss in pairs and in groups. They are free to express their own opinions and develop ideas and new ways of thinking. The discussion and debate can cause conflicts to be resolved, that's why language teaching may in large part contribute to situational skills and social skills.

During the organization of work in the classroom, the teacher must be attentive to find the symptom of intolerance that may arise from one moment to another, such as behavior intended to intimidate and humiliate others, for example.

The teachers' professional development (Villegas-Reimers, E. 2003) has a significant impact on the success of educational reforms and on students' learning.

The European Union Ministers of Education noted in 2008 (TALIS \& OECD. 2010) : school education in an important means of passing on the values, skills, knowledge and attitudes required for democracy, citizenship, intercultural dialogue and personal development. Schools therefore have a duty to provide their pupils with an education which will enable them to adapt to an increasingly globalised, competitive, diversified and complex environment, in which creativity, the ability to innovate, a sense of initiative, entrepreneurship and commitment to continue learning are just as important as the specific knowledge of a given subject.

The education and training of teachers is therefore "a crucial element in the modernization of European education and training system" (TALIS \& OECD. 2010).

Through linguistic knowledge, students should obtain key competencies such as: cognitive competencies, affective competencies, social competencies and the operational skills. (Haloçi, A.2010).

These competencies imply recognition of the rules of collective life, recognition of the historical and cultural dimension, speech-making capacity, and the argumentation and reflection capacity. Also, they insist in the creation of affective relations and cooperation within the group. Students should have the ability to resolve conflicts according to democratic principles.

Recommendation Nr. R (85) 7 of the Committee of Ministers of the Council of Europe on education and human rights in schools are key skills for democratic citizenship, especially in educational abilities:

To learn to recognize and accept differences

To establish constructive and non- oppressive relationships with others

To resolve conflicts non-violently

To assume responsibility

To participate in decisions

To understand the use of mechanisms to protect human rights at the local, regional, European and global level.

\section{Conclusions}

Language teaching in Europe, especially at school level, has been influenced by considerations of mere communication over content of communication and its role.

Teaching is much more than giving knowledge. It involves classroom management, lesson preparation, and organization of teaching and learning activities, creating and maintaining a certain atmosphere, evaluation and feedback.

Albania is a developing country which aims at its integration with the EU. Our students and pupils aspire to become European citizens with all the rights and obligations, as foreseen in international conventions and recommendations. To achieve this we have to:

teach the students how to improve in order to participate in discussions, decision - taking, how to develop critical thinking, and be involved into actions

teach the pupils and students how to be tolerant and respectful of diversity point out to them that a foreign language learning is a process far broader than simply learning the lexicon or grammar rules. introduction of the European citizen model through foreign language learning should be seen as a motivating element for pupils and students the pupils and 
students should get acquainted with the different symptoms of intolerance and discrimination so that they be prepared to avoid them in their communication with the others, in particular people of the country which language he is learning

be able to distinguish at the very start the symptoms of intolerance and discrimination. To this end, the teacher should take part in different trainings to improve his formation and professional skills through programmes offered by the EU institutions

The education institutions should offer to the students programs that bring them closer to the ideas of globalization, diversity, tolerance, etc, that is, the real model of the European citizen which one day they would feel like.

\section{References}

CERF. (2002). Common European Framework of reference for languages. Council of Europe. Strasbourg. Cambridge university press.

Conseil de l'Europe, (2001). Le Cadre européen Commun de references pour les langues: apprendre, enseigner, évaluer : Paris. Didier.

Council of Europe. (2002). Common European Framework of reference for languages. Cambridge University Press.

English Dictionary for Advancer Learners (2001), London. Harper Collins Publishers.

Gilherme, M.,( 2002). Critical Citizen for an Intercultural World. Foreign Language Education as Cultural Politics. ICE Language for intercultural communication and Education. Multilingual Matters. London.

http://assembly.coe.int/ASP/Doc/RefRedirectEN.asp\%3FDoc. Assembly debate on 23 September 1998 (29th Sitting) (see Doc. 8173, report of the Committee on Culture and Education, rapporteur: Mr Legendre). Text adopted by the Assembly on 23 September 1998 (29th Sitting).

http://europa.eu/legislation_summaries/institutional_affairs/treaties/treaties_maastricht_en.htm. Treaty of Maastricht on European Union, 7 February 1992. http://www.eurotreaties.com/maastrichtec.pdf. 10 may 2014

Legendre, J.(1998). Memorandum explicatif sur le rapport traitant de la Diversification linguistique. http://stars.coe.fr/doc/doc98/EDOC8173.htm

OECD, (2010). Teachers' Professional Development. Europe in international comparison. Analysis of teachers' professional development based on the OECD's Teaching and Learning International Survey (TALIS). Education and culture DG. European Union. Luxembourg.

Puren, C. 1988. Histoire des méthodologies de l'enseignement des langues. Paris. NATHAN cle international.

TALIS \& OECD, 2010, Teachers' Professional Development, Europe in international comparison. Ed. Professor Jaap Scheerens, Universitu of Twente. Luxembourg: Office for Official Publications of European Union.

Tardieu, C.(1999). Le professeur Citoyen. Bourg-la-Reine : Edition M. T

Villegas-Reimers, E., (2003), Teacher professional development an international review of the literature, UNESCO, International Institute for Educational planning. www.unesco.org./iiep

Haloçi, A. (2010), Les copmétences professionnelles d'un enseignant de langue. Monographie. Tirane. Redona publishing..

Tables

\begin{tabular}{|l|l|l|l|l|}
\hline $\begin{array}{l}\text { Learning a foreign } \\
\text { language means }\end{array}$ & To know a langage: & $\begin{array}{l}\text { To know another } \\
\text { way of thinking }\end{array}$ & $\begin{array}{l}\text { To know another } \\
\text { civilisation }\end{array}$ & No replies \\
\hline pupils & $52(48 \%)$ & $32(19 \%)$ & $46(25 \%)$ & $6(8 \%)$, \\
\hline students & $61(48 \%)$ & $38(13 \%)$ & $61(41 \%)$ & 0 \\
\hline
\end{tabular}

Fig. 1

Do you find that the two concepts, the European citizen and national citizen

Divided
Complementary
No replies 


\begin{tabular}{|l|l|l|l|}
\hline $\begin{array}{l}\text { are divided or } \\
\text { complementary? }\end{array}$ & & \\
\hline pupils & $52(81 \%)$, & $10(16 \%)$ & $2(3 \%)$ \\
\hline students & $18(31 \%)$ & $39(66 \%)$ & $5(3 \%)$ \\
\hline
\end{tabular}

Fig.2

\begin{tabular}{|l|l|l|l|}
\hline $\begin{array}{l}\text { Do the foreign languages } \\
\text { courses prepare you to the } \\
\text { mental and physical } \\
\text { mobility } \begin{array}{r}\text { regarding } \\
\text { European citizen model? }\end{array}\end{array}$ & Yes & No & No replies \\
\hline pupils & $45(73 \%)$ & $12(19 \%)$ & $7(8 \%)$ \\
\hline students & $52(78 \%)$ & $8(12 \%)$ & $2(10 \%)$ \\
\hline
\end{tabular}

Fig.3

\begin{tabular}{|l|l|l|l|l|}
\hline $\begin{array}{l}\text { Do you organize } \\
\text { debate activities in } \\
\text { the class of foreign } \\
\text { language? }\end{array}$ & Yes & No & Some times & No replies \\
\hline Pupils & $25(39 \%)$ & $12(19 \%)$ & $20(31 \%)$ & $7(11 \%)$ \\
\hline students & $48(72 \%)$ & $8(12 \%)$ & $4(10 \%)$ & $2(6 \%)$ \\
\hline
\end{tabular}

Fig.4

\begin{tabular}{|l|l|l|l|l|}
\hline $\begin{array}{l}\text { Do you feel active } \\
\text { during the debate? }\end{array}$ & Yes & No & Some times & No replies \\
\hline Pupils & $13(22 \%)$ & $24(41 \%)$ & $20(34 \%)$, & $7(3 \%)$, \\
\hline students & $39(58 \%)$ & $12(18 \%)$ & $9(13 \%)$ & $2(11 \%)$ \\
\hline
\end{tabular}

Fig.5

\begin{tabular}{|l|l|l|l|l|}
\hline $\begin{array}{l}\text { Have you ever felt } \\
\text { prejudiced? }\end{array}$ & Yes & No & Some times & No replies \\
\hline Pupils & $13(32 \%)$, & $18(23 \%)$, & $24(42 \%)$, & $9(3 \%)$, \\
\hline students & $8(14 \%)$ & $18(31 \%)$ & $23(40 \%)$ & $13(15 \%)$ \\
\hline
\end{tabular}

Fig.6
If during the debate in the class, some "conflict" situations are created, how are they resolved?

\begin{tabular}{l|l} 
By you & By teacher
\end{tabular} 


\begin{tabular}{|l|l|l|l|}
\hline & & & \\
\hline Pupils & $12(19 \%)$ & $28(44 \%)$, & $24(37 \%)$, \\
\hline students & $41(50 \%)$ & $16(30 \%)$ & $5(20 \%)$ \\
\hline
\end{tabular}

Fig.7

\begin{tabular}{|l|l|l|l|l|l|}
\hline $\begin{array}{l}\text { During the } \\
\text { discussion, which } \\
\text { are the symptoms } \\
\text { that most } \\
\text { appeared of } \\
\text { intolerance? }\end{array}$ & Ridiculous & Prejudice & Stereotype & Ostracism & No replies \\
\hline Pupils & $48(75 \%)$ & $2(3 \%)$ & $0(0 \%)$, & $0(0 \%)$, & $14(22 \%)$, \\
\hline students & $12(17 \%)$ & $27(37 \%)$ & $20(27 \%)$ & $0(0 \%)$ & $3(19 \%)$ \\
\hline
\end{tabular}

Fig. 8

\begin{tabular}{|l|l|l|l|l|}
\hline $\begin{array}{l}\text { during foreign } \\
\text { language teaching, } \\
\text { have you dealt } \\
\text { directly with issues } \\
\text { related to the } \\
\text { knowledge of the } \\
\text { pattern of European } \\
\text { citizens? }\end{array}$ & No & Some times & No replies \\
\hline Pupils & $112(18 \%)$, & $31(46 \%)$, & $5(7 \%)$, & \\
\hline students & $26(36 \%)$ & $7(10 \%)$ & $23(32 \%)$ & $16(24 \%)$, \\
\hline
\end{tabular}

Fig.9 